\title{
INOVASI PENINGKATAN KAPASITAS BENDAHARA DESA DALAM PENGELOLAAN KEUANGAN DESA
}

\author{
${ }^{1}$ Muhamad HasisudinDr, ${ }^{2}$ Kaharuddin Jenod, M.Eng. ${ }^{3}$ Dr.Ir. Muhammad Saleh, M.Si.
}

Program Studi Manajemen Inovasi

${ }^{1,2,3 *}$ Sekolah Pasca Sarjana Universitas Teknologi Sumbawa

*Corresponding Author email: muhammad.saleh@uts.ac.id

\begin{abstract}
Diterima :
Bulan Juni 2020

Abstrak

Penelitian ini bertujuan untuk mengetahui kepatuhan penatausahaan yang telah dilakukan oleh Pemerintah Desa dengan Peraturan Menteri Dalam Negeri Nomor 113 Tahun 2014 tentanh Pengelolan Keuangan Desa dan Peraturan Perundang-undangan yang berlaku. Metode penelitian yang digunakan penelitian kualitatif yang bersifat deskriptif analisis. Data sekunder diperoleh dari studi pustak, sedangkan data primer

Diterbitkan :

Bulan Juli 2020 didapatkan melalui hasil penelitian yang dilaksanakan di lokasi penelitian di kabupaten Sumbawa dengan jumlah desa yang ada di Kabupaten Sumbawa sebanyak 157 Desa, dimana meneliti 8 Desa yang menjadi sample penelitian tersebut, adapun lokasi penelitian yang dilaksanakan di Desa Labuhan Sumbawa, Uma Beringin, Tepal, Batu Rotok, Pulau Kaung, Pulau Bungin, Lekong dan Mapin Rea dan Dinas Pemberdayaan

Keyword : Masyarakat dan Desa (Dinas PMD) Kabupaten Sumbawa. Penelitian ini bertujuan untuk Penatausahaan Desa, Pengelolaan Keuangan Desa dan terlambat penyampaian pelaporan keuangan oleh sintesis pengelolaan keuangan desa dalam pengelolaan Dana Desa. Jenis penelitian ini adalah penelitian kualitatif dengan pendekatan analisis deskriptif. Penelitian ini dilakukan dengan menggunakan tekhnik dokumentasi dan wawancara dengan pihakpihak yang terlibat dalam pengelolaan Dana Desa. Hasil deskripsi didapat melalui analisa Permendagri No. 113 Tahun 2014 dengan membandingkan realisasi di lapangan. Pengelolaan Dana Desa dari tahap perencanaan, pelaksanaan, penatausahaan, pelaporan dan pertanggungjawaban secara garis besar dapat dikatakan sudah sesuai dengan bendahara desa. permendagri No. 113 Tahun 2014 meskipun terdapat beberapa hal dalam perencanaan, pelaksanaan dan penatausahaan yang masih belum sesuai dengan target waktu.
\end{abstract}

\section{PENDAHULUAN}

Pemerintah Desa merupakan salah satu bentuk organisasi non profit yang bertujuan meningkatkan pelayanan kepada masyarakat umum yang berupa peningkatan keamanan, peningkatan kesehatan, peningkatan pembangunan dan lainlainnya. Desa memiliki aspek sebagai lembaga ekonomi dikarenakan memiliki bentuk pengeluaran guna membiayai kegiatan-kegiatan yang dilakukan satu sisi, dan di sisi lain harus pelakukan berbagai upaya penghasilan guna menutupi seluruh biaya tersebut. (Jurnal Akuntansi, Ekonomi dan Manajemen Bisnis, Halaman 12)

Sebagaimana halnya suatu instansi pemerintah yang lain, pemerintah desa juga berusaha untuk mencegah atau menghindari pemborosan dan hal-hal yang dianggap merugikan karena hal-hal demikian akan membawa pengaruh buruk bagi keuangan desa. Untuk menjamin adanya akuntabilitas dalam pengelolaan keuangan, maka diperlukan suatu sistem akuntansi keuangan yang tepat untuk diterapkan. Sistem akuntansi keuangan merupakan suatu hal yang penting untuk diperhatikan dalam pemerintahan desa dikarenakan dapat digunakan sebagai alat pengatur kegiatan keuangan dan melindungi kekayaan milik desa. (Jurnal Akuntansi, Ekonomi dan Manajemen Bisnis, Halaman 12)

Akuntansi keuangan desa merupakan salah satu bidang dalam akuntansi sektor publik yang mendapat perhatian besar dari pihak publik ataupun masyarakat. Dengan lahirnya Undang-undang Nomor 23 Tahun 2014 tentang Pemerintahan daerah yang mana telah diperbaharui dengan Undangundang Nomor 9 Tahun 2015 menjelaskan bahwa daerah dapat menyelenggarakan otonomi daerah secara luas dan daerah diberikan kesempatan untuk mengurus daerah masing-masing, Undang-undang Nomor 6 Tahun 2014 tentang desa, Peraturan Pemerintah (PP) Nomor 71 Tahun 2010 tantang Standar Akuntasi Pemerintah, menjadi titik awal dimulainya sisitem informasi pembangunan kawasan perdesaan. Dengan adanya otonmi daerah maka setiap daerah dapat mengatur kebutuhan daerah mereka sendiri, baik dari sisi perencanaan, peaksanaan maupun pembangunan daerah yang mempunyai batas-batas wilayah yang berwenag mengatur dan mengurus urursan pemerintahan dan kepentingan masyarakat setempat menurut prakarsa 
sendiri berdasarkan aspirasi masyarakat. Peran serta warga masyarakat sangat penting untuk menyalurkan aspirasi, pemikiran dan kepentingan dalam penyelenggaraan pemerintah daerah. Adanya Undang-undang tersebut telah memberi kewenagan yang lebih luas kepada Desa tingkat kecamatan untuk Menyelenggarkan semua urusan mulai dari perencanaan, penganggaran, penatausahaan pelaporan serta pengawasan, sehingga mendorong desa untuk lebih memberdayakan semua potensi yang dimiliki dalam rangka membangun dan mengembangkan desanya. Akuntansi keuangan desa merupakan salah satu bidang dalam akuntansi sektor publik yang mendapat perhatian besar dari pihak publik ataupun masyarakat. Dengan lahirnya Undang-undang Nomor 23 Tahun 2014 tentang Pemerintahan daerah yang mana telah diperbaharui dengan Undang-undang Nomor 9 Tahun 2015 menjelaskan bahwa daerah dapat menyelenggarakan otonomi daerah secara luas dan daerah diberikan kesempatan untuk mengurus.

Masyarakat Indonesia secara turuntemurun hidup dalam suatu kelompok masyarakat yang disebut dengan desa. Didalamnya terdapat kesatuan hukum yang memiliki batas wilayah yang berwenang untuk mengatur dan mengurus urusan pemerintahan serta kepentingan masyarakat setempat berdasarkan prakarsa masyarakat, hak asal usul dan atau hak tradisional yang diakui dan dihormati dalam sistem Pemerintahan Negara Kesatuan Republik Indonesia (pasal 1 ayat 1 Undang - undang No 6 Tahun 2014 tentang Desa). Pemerintahan Daerah merupakan penyelenggara urusan Pemerintahan dan kepentingan masyarakat setempat dalam sistem Kesatuan Pemerintahan Negara Kesatuan Republik Indonesia (pasal 1 ayat 2 Undang - undang No 6 Tahun 2014 tentang Desa). Pemerintah Desa dalam pembagian wilayah Administrasi Indonesia berada dibawah Kecamatan, Desa dipimpin oleh seorang kepala desa. Penyelenggara pemerintahan desa merupakan sub sistem dari penyelenggaraan pemerintahan, sehingga desa memiliki kewenangan untuk mengatur dan mengurus kepentingan masyarakat (Wijaja, 2013).

Keberadaan desa merupakan cermin utama berhasil tidaknya suatu pemerintahan suatu negara serta pelaksanaan kehidupan demokrasi di Daerah.Hal ini sangat dibutuhkan peran serta masyarakat desa sehingga terwujud kehidupan yang demokratis. Penyelenggaraan pemerintahan Desa yang dilaksanakan oleh Kepala Desa dan Perangkat Desa. Pelaksanaan pemerintah tersebut diawasi oleh Badan Permusyawaratan Desa (BPD). BPD merupakan lembaga yang ada dalam penyelenggaraan pemerintahan desa. BPD sebagai mitra kerja yang perannya sangat penting dalam mendukung penyelenggaraan pemerintahan desa karena merupakan lembaga yang paling dekat dengan masyarakat. Diantaranya dalam penyerapan aspirasi masyarakat desa, legislasi dan pengawas termasuk dalam pengelolaan dana desa.

Bendahara desa mempunyai tugas untuk menerima, menyimpan, menyetorkan, menatausahakan, membayarkan dan mempertanggung-jawabkan keuangan desa dalam rangka pelaksanaan APBDesa. Bendahara desa harus membuat laporan pertanggungjawaban atas penerimaan dan uang yang menjadi tanggungjawabnya melalui laporan pertanggungjawaban. Begitu banyak tugas dan tanggungjawab bendahara desa sehingga tentulah Bendahara Desa harus memahami pengelolaan keuangan Desa secara baik dan benar.

Pengelolaan Keuangan Desa dimulai dari perencanaan, kemudian diikuti dengan penganggaran, penatausahaan pelaporan, pertanggungjawaban dan diakhiri dengan pengawasan. Dari siklus pengelolaan keuangan desa diatas, bendahara desa menjadi bagian yang cukup penting, terutama pada tahap penatausahaan, pelaporan dan pertanggungjawaban.

$$
\text { Dalam penatausahaan pengelolaan }
$$

keuangan desa beberapa pembukuan wajib diselenggarakan oleh bendahara desa. Penatausahaan Penerimaan dan Pengeluaran Desa mewajibkan Bendahara desa membuat Buku Kas Umum, dan beberapa buku pembantu lainnya.Pemahaman yang baik atas Pengelolaan Keuangan Desa akan sangat membantu para Kepala Desa dan perangkat desa lainnya termasuk bendahara desa. Nah, disinilah pemerintah daerah memainkan peranan yang penting dalam memberikan perhatian atas kapabilitas para penyelenggara pengelola keuangan desa, dengan membuat suatu petunjuk pengelolaan keuangan desa yang lebih rinci dalam rangka penyeragaman penyelenggaraan penatausahaan dan pertanggungjawaban keuangan desa.

$\begin{array}{cccc}\text { Asistensi ataupun bimbingan } & \text { teknik } \\ \text { pengelolaan keuangan } & \text { desa } & \text { secara }\end{array}$
berkesinambungan atas bendahara desa dapat menjadi salah satu alternatif dalam meningkatkan kemampuan para bendahara desa. Tidak saja bimbingan teknik bagi bendahara desa, tetapi juga bagi para Kepala Desa, Sekretaris Desa sehingga diharapkan akan ada pemahaman yang sama atas pengelolaan keuangan desa yang tentunya dapat membantu kelancaran pelaksanaan pengelolaan keuangan desa.

Bendahara desa adalah unsur staf sekretariat desa yang membidangi urusan administrasi keuangan untuk menatausahaan keuangan desa. Bendahara desa merupakan bagian dari PTPKD.PTPKD atau Pelaksana Teknis Pengelolaan Keuangan Desa merupakan unsur 
perangkat desa yang membantu Kepala Desa untuk melaksanakan pengelolaan keuangan desa. Bendahara di jabat oleh staf pada Urusan Keuangan. Bendahara mempunyai tugas menerima, menyimpan, menyetorkan / membayar, menatausahaan, dan mempertanggungjawabkan penerimaan pendapatan desa dan pengeluaran pendapatan desa dalam rangka pelaksanaan APBDesa. Bendahara Desa wajib melakukan pencatatan setiap penerimaan dan pengeluaran serta melakukan tutup buku setiap akhir bulan secara tertib. Bendahara Desa wajib mempertanggungjawabkan uang melalui laporan pertanggungjawaban. Laporan pertanggungjawaban disampaikan setiap bulan kepada Kepala Desa paling lambat tanggal 10 bulan berikutnya.

Dokumen yang digunakan oleh bendahara dalam melakukan penatausahaan penerimaan dan pengeluaran antara lain, buku kas umum, buku kas pembantu pajak dan buku bank. Buku kas umum digunakan untuk mencatat seluruh bukti transaksi keuangan desa. Buku kas pembantu pajak digunakan untuk mencatat bukti transaksi terkait dengan pemungutan maupun penyetoran pajak oleh bendahara desa. Buku bank digunakan untuk mencatat bukti transaksi terkait dengan penerimaan maupun pengeluaran melalui bank.

Kesuksesan didalam mengelola pemerintah desa yang berujung pada peningkatan kemajuan dan kesejahteraan masyarakat desa, untuk era sekarang ini masih menjadi suatu hal yang bisa dibilang sangat langka. Dahulu pemerintahan desa memiliki peran atau wewenang yang kecil didalam pembangunan. Namun sejak dikeluarkannya UU Desa No. 6 Tahun 2014 pemerintah desa mulai diberi kejelasan tentang status dan kepastian hukum. Sejak diberlakukannya PP No 60 Tahun 2014 dan perubahannya PP No 22 Tahun 2015 tentang Dana Desa Bersumber dari APBN, setiap desa diberi dana desa sebanyak Rp. 1 Miliyar, yang diprioritaskan untuk pembangunan dan pemberdayaan masyarakat desa. Dana Desa adalah dana yang bersumber dari Anggaran Pendapatan dan Belanja Negara yang diperuntukkan bagi desa yang ditransfer melalui Anggaran Pendapatan dan Belanja Daerah Kabupaten/Kota dan digunakan untuk membiayai penyelenggara pemerintahan, pelaksanaan pembangunan, pembinaan kemasyarakatan dan pemberdayaan kemasyarakatan (Peraturan Pemerintah Nomor 22 Tahun 2015).

Dengan disahkannya UU Nomor 6 Tahun 2014 tentang Desa, desa diberikan kesempatan yang besar untuk mengurus tata pemerintahannya sendiri serta pelaksanaan pembangunan untuk meningkatkan kesejahteraan dan kualitas hidup masyarakat desa. Selain itu pemerintah desa diharapkan untuk lebih mandiri dalam mengelola pemerintahan dan berbagai sumber daya alam yang dimiliki, termasuk di dalamnya pengelolaan keuangan dan kekayaan milik desa. Begitu besar peran yang diterima oleh desa, tentunya disertai dengan tanggung jawab yang besar pula. Oleh karena itu pemerintah desa harus bisa menerapkan prinsip akuntabilitas dalam tata pemerintahannya, sehingga penyelenggaraan pemerintahan desa harus dapat dipertanggungjawabkan kepada masyarakat sesuai dengan ketentuan yang berlaku.

Pengelolaan Dana Desa bukanlah hal yang mudah namun memerlukan sistem yang juga harus dibuat secara profesional. Mulai dari segi perencanaan, desa harus membentuk musyawarah desa untuk menetukan belanja bagi Dana Desa pada periode ke depan. Penatausahaannnya pun harus menggunakan sistem yang telah memanfaatkan teknologi informasi. Tidak hanya sistem, Sumber Daya Manusia (SDM) atau perangkat penyelenggara desa pun harus memiliki kapabilitas dalam mengelola dana tersebut. Dengan adanya Dana Desa yang tepat sasaran, tepat jumlah, dan tepat waktu serta dikelola dengan efisien, efektif, dan ekonomis, diharapkan kesejahteraan masyarakat dapat meningkat dengan cepat terutama bagi masyarakat desa dalam peningkatan kesejahteraannya (BPKP, 2017).

Penyelenggaraan tugas dan fungsi pemerintahan yang akuntabel dalam era otonomi menjadi tuntutan publik melalui perwujudan penyelenggaraan pemerintahan yang baik (good governance government). Pemerintahan yang baik harus memenuhi kriteria, yaitu: accountability, transparancy, predictability dan participation (Bappenas, 2003). Terkait dengan akuntabilitas, Stanbury (2003) dalam Mardiasmo (2006) menyatakan bahwa akuntabilitas merupakan bentuk kewajiban pelaksana suatu kegiatan guna mempertanggungjawabkan pelaksanaan tugas sesuai tujuan dan sasaran yang telah ditetapkan sebelumnya, melalui suatu media pertanggungjawaban yang dilaksanakan secara periodik. Berdasarkan hal ini, maka memberikan penekanan yang tidak hanya terbatas pada proses dan hasil yang baik, namun diikuti pula oleh pengungkapan dalam bentuk laporan untuk diketahui dan dinilai oleh publik.

Akuntabilitas pengelolaan keuangan pada suatu entitas, diwujudkan melalui publikasi atas laporan hasil pengelolaan keuangannya kepada publik. Governmental Accounting Standards Board (1999) menyatakan bahwa akuntabilitas merupakan dasar pelaporan keuangan di pemerintahan yang didasari oleh adanya hak masyarakat untuk mengetahui dan menerima penjelasan atas pengumpulan sumber daya serta penggunaannya. Pemerintah Indonesia juga berupaya mewujudkan akuntabilitas melalui UU No. 17/2003 tentang Keuangan Negara. Regulasi ini merupakan upaya 
konkrit pemerintah untuk mewujudkan transparansi dan akuntabilitas pengelolaan keuangan pemerintah, dengan menyampaikan laporan pertanggungjawaban berupa laporan keuangan. Selanjutnya pemerintah menerbitkan PP. No. 71/2010 tentang Standar Akuntansi Pemerintah yang dijadikan pedoman dalam menyusun laporan keuangan oleh pemerintah pusat dan pemerintah daerah. (Lembaran Negara Republik Indonesia No. 123.)

Laporan keuangan yang dihasilkan pemerintah akan digunakan oleh beberapa pihak yang berkepentingan sebagai dasar untuk pengambilan keputusan. Oleh karena itu informasi yang disajikan dalam laporan keuangan harus bermanfaat dan sesuai kebutuhan pemakai. Agar informasi tersebut dapat mendukung dalam pengambilan keputusan dan dapat dipahami oleh para pemakai, maka informasi akuntansi sebagaimana disebutkan dalam PP No. 71/2010 harus mempunyai beberapa karakteristik kualitatif. Karakteristik kualitatif laporan keuangan tersebut merupakan ukuran-ukuran normatif yang perlu diwujudkan dalam informasi akuntansi sehingga dapat memenuhi tujuannya. Karakteristik kualitatif laporan keuangan pemerintah yang disebutkan dalam PP No. 71/2010 adalah: relevan, handal, dapat dibandingkan, dan dapat dipahami.

Suwarjono (2013) dan Fathi (2013) secara spesifik menyatakan bahwa keterandalan dan ketepatwaktuan merupakan unsur nilai informasi yang diperlukan oleh pemakai sebagai dasar dalam pengambilan keputusan. Lebih lanjut dijelaskan bahwa keterandalan merupakan kemampuan informasi untuk memberikan keyakinan bahwa informasi tersebut benar atau valid, sedangkan ketepat waktuan merupakan tersedianya informasi bagi pembuat keputusan pada saat dibutuhkan sebelum informasi tersebut kehilangan kekuatan untuk mempengaruhi keputusan. Hal ini sejalan dengan amanat PP No. 71/2010 yang menyatakan bahwa pemerintah wajib memperhatikan Informasi yang disajikan dalam laporan keuangan untuk keperluan perencanaan, pengendalian, dan pengambilan keputusan.

Dengan aplikasi keuangan desa ini, diharapkan pemerintah desa dapat mewujudkan tata kelola keuangan desa yang bersih, tertib, efektif dan efisian. Proses pengawasan dan pemeriksaan pertanggungjawaban keuangan desa juga lebih mudah diterapkan.

\section{LANDASAN TEORI}

\section{Pengertian Inovasi}

Kata inovasi dapat diartikan sebagai "proses" atau "hasil" pengembangan dan atau pemanfaatan atau mobilisasi pengetahuan, keterampilan (termasuk keterampilan teknologis) dan pengalaman untuk menciptakan atau memperbaiki produk, proses yang dapat memberikan nilai yang lebih berarti. Menurut Rosenfeld dalam Sutarno (2012:132), inovasi adalah transformasi pengetahuan kepada produk, proses dan jasa baru, tindakan menggunakan sesuatu yang baru. Sedangkan menurut Mitra pada buku tersebut dan pada halaman yang sama, bahwa inovasi merupakan eksploitasi yang berhasil dari suatu gagasan baru atau dengan kata lain merupakan mobilisasi pengetahuan, keterampilan teknologis dan pengalaman untuk menciptakan produk, proses dan jasa baru. Namun menurut Vontana (2009:20), inovasi adalah kesuksesan ekonomi dan sosial berkat diperkenalkannya cara baru atau kombinasi baru dari cara-cara lama dalam mentransformasi input menjadi output yang menciptakan perubahan besar dalam hubungan antara nilai guna dan harga yang ditawarkan kepada konsumen dan/atau pengguna, komunitas, sosietas dan lingkungan.

Konsep Kapasitas Sumber Daya Manusia

Kinerja sumber daya manusia adalah kemampuan seseorang atau individu, suatu organisasi (kelembagaan) atau suatu sistem untuk melaksanakan fungsi - fungsi atau kewenangannya untuk mencapai tujuannya secara efektif dan efisien. Kapasitasnya harus dilihat sebagai kemampuan untuk mencapai kinerja, untuk menghasilkan keluaran-keluaran (output) dan hasil-hasil (outcomes).

Hasil penelitian Karmila (2013) dalam Rachmawati (2014), Kapasitas sumber daya manusia adalah kemampuan seseorang atau individu, suatu organisasi (kelembagaan) atau suatu sistem untuk melaksanakan fungsi-fungsi atau kewenangannya untuk mencapai sebagai kemampuan untuk mencapai kinerja, untuk menghasilkan keluaran-keluaran (output) dan hasilhasil (outcomes).

pengembangan kapasitas adalah proses yang dialami oleh individu, kelompok dan organisasi untuk memperbaiki kemampuan mereka dalam melaksanakan fungsi mereka dan mencapai hasil yang diinginkan. Dari pengertian ini kita dapat memberi penekanan pada dua hal penting: 1) pengembangan kapasitas sebagian besar berupa proses pertumbuhan dan pengembangan internal, dan 2) upaya- upaya pengembangan kapasitas haruslah berorientasi pada hasil.

\section{Gambaran Umum Pengelolaan Keuangan Desa}

Pengertian Keuangan Desa menurut UU Desa adalah semua hak dan kewajiban desa yang dapat dinilai dengan uang serta segala sesuatu berupa uang dan barang yang berhubungan dengan pelaksanaan hak dan kewajiban desa. Hak dan kewajiban tersebut menimbulkan pendapatan, belanja, pembiayaan yang perlu diatur dalam pengelolaan keuangan desa yang baik. Siklus 
pengelolaan keuangan desa meliputi perencanaan, penatausahaan, pelaporan, dan pertanggungjawaban dengan prodisasi 1 (satu) tahun anggaran, terhitung mulai 1 Januari sampai dengan 31 Desember. Keuangan desa dikelola berdasarkan asas-asas transparan, akuntabel, partisipasif, serta dilakukan dengan tertib dan disiplin anggaran. Akuntabilitas keuangan desa tidak hanya bersifat horisontal antara pemerintah desa dengan Badan Permusyawaratan Desa (BPD), tetapi juga harus bersifat vertikal antara kepala desa dengan masyarakat desa dan atasan kepala desa. Dokumen publik tentang pengelolaan keuangan desa harus dapat diakses oleh masyarakat desa, serta tidak diskriminasi terhadap satu golongan tertentu terkait dengan pengelolaan keuangan desa.

Pengelolaan Keuangan Desa jika tidak diimbangi dengan kemampuan SDM yang handal, justru akan menjadi bom waktu bagi desa, sehingga dihawatirkan akan banyak yang terjerat kasus hukum terutama dalam pengelolaan keuangan dan pelaksanaan pengadaan barang/jasa di desa karena kurang memahami prosedur dan pertanggungjawabannya. Untuk mengantisipasi terjadinya permasalahan hukum yang mungkin dapat menimpa aparatur desa perlu diselenggarakan kegiatan pelatihan - pelatihan untuk meningkatkan kompetensi aparatur desa, sehingga memiliki pemahaman dan keterampilan atas tatacara Perencanaan, Pengelolaan dan Pertanggungjawaban Keuangan Desa.

Menyadari betapa pentingnya peningkatan kapasitas aparatur pemerintahan desa untuk melaksanakan amanat UU Desa ini, perlu memberikan pelatihan peningkatan kopetensi bagi aparatur desa terutama bendahara desa berupa pelatihan dalam bentuk workshop penelola keuangan desa.

Pengelolan Keuangan Desa berdasarkan Permendagri No. 113 Tahun 2014 tentang pengelolaan keuangan desa yaitu sebagai berikut

a. Perencanaan

Perencanaan pembangunan desa diselenggarakan dengan melibatkan masyarakat desa melalui musyawarah perencanaan pembangunan desa. Secara dokumentatif pencanaan dan pembangunan desa tertuang dalam Pembangunan Jangka Menengah Desa (RPJMDes) yang berlaku 6 (enam) tahun dan Rencana Pembangunan Tahunan Desa atau yang disebut dengan Rencana Kerja Pemerintah Desa (RKPDes) dan Anggaran Pendapatan dan Belanja Desa (APBDes) yang berlaku 1 (satu) tahun. RKPDes harus mengacu kepada RPJMDes. RKPDes merupakan rencana program kegiatan desa yang dijadikan sebagai acuan dalam menyusun APBDes.
RPJMDes disusun dan ditetapkan pada saat kepala desa dilantik melalui musyawarah desa. RKPDes disusun dan ditetapkan pemerintah desa melalui musyawarah rencana pembangunan desa (musrenbangdes) yang dihadiri oleh masyarakat dan unsur-unsur desa pada saat mendekati akhir dari tahun anggaran berjalan. Setelah penetapan RKPDes langkah selanjutnya adalah menetapkan APBDes. Sebelum menetapkan APBDes, sekretaris desa menyusun rancangan anggaran pendapatan dan belanja desa (RAPBDes).

Dokumen RAPBDes diserahkan kepada kepala desa, selanjutnya dibawa kedalam forum musyawarah desa (musdes) untuk ditetapkan menjadi APBDes berdasarkan kesepakatan bersama dengan Badan Permusyawaratan Desa (BPD). APBDes ditetapkan paling lambat pada bulan Desember tahun berjalan. RKPDes dan APBDes ditetapkan melalui peraturan desa (perdes). Perdes merupakan produk kesepakatan antara pemerintah desa dan BPD.

b. Penganggaran

Penganggaran dilaksanakan setelah RKPDes ditetapkan. Rencana kegiatan dan Rencana Anggaran Biaya yang telah ditetapkan dalam RKPDes dijadikan pedoman dalam proses penganggarannya. Anggaran Pendapatan dan Belanja Desa (APBDes) merupakan rencana anggaran keuangan tahunan pemerintah desa yang ditetapkan untuk menyelenggarakan program dan kegiatan yang menjadi kewenangan desa.

c. Pelaksanaan

Dalam pelaksanaan pengelolaan keuangan desa, terdapat beberapa prinsip umum yang harus ditaati yang mencakup penerimaan dan pengeluaran. Prinsip itu diantaranya bahwa seluruh penerimaan dan pengeluaran desa dilaksanakan melalui Rekening Kas Desa. Pelaksana kegiatan mengajukan pendanaan untuk melaksanakan kegiatan harus disertai dengan dokumen Rencana Anggaran Biaya (RAB).

d. Penatausahaan

Penatausahaan keuangan desa adalah kegiatan pencatatan yang khususnya dilakukan oleh Bendahara desa. Bendahara desa wajib melakukan pencatatan terhadap seluruh transaksi yang ada berupa penerimaan dan pengeluaran. Bendahara Desa melakukan pencatatan secara sistematis dan kronologis atas transaksi-transaksi keuangan yang terjadi.

e. Pelaporan

Dalam melaksanakan tugas, kewenangan, hak, dan kewajibannya dalam pengelolaan keuangan desa, kepala desa memiliki kewajiban untuk 
menyampaikan laporan. Laporan tersebut bersifat periodik semesteran dan tahunan yang disampaikan ke Bupati/Walikota. Laporan semester pertama berupa laporan realisasi APBDesa. Laporan realisasi semester pertama disampaikan paling lambat pada bulan Juli tahun berjalan. Laporan semester akhir tahun disampaikan paling lambat pada akhir bulan Jjanuari pada tahun berikutnya.

f. Pertanggungjawaban

Laporan pertanggungjawaban realisasi pelaksanaan APBDes setiap akhir tahun anggaran disampaikan kepada Bupati/Walikota melalui camat terdiri dari pendapatan, belanja, dan pembiayaan yang telah ditetapkan dengan peraturan desa. Setelah pemerintah desa dan BPD telah sepakat terhadap laporan pertanggungjawaban realisasi pelaksanaan APBDes dalam bentuk peraturan desa, maka Perdes ini disampaikan kepada Bupati/Walikota sebagai bagian tidak terpisahkan dari laporan penyelenggaraan pemerintahan desa. Laporan pertanggung jawaban diinformasikan kepada masyarakat secara tertulis dan dengan media informasi yang mudah diakses oleh masyarakat.

\section{MATODE PENELITIAN}

Penelitian ini menggunakan metode penelitian kualitatif dengan pendekatan eksploratori (exploratory approach.) Metode penelitian kualitatif menurut Sugiyono (2015:1) sering disebut metode penelitian naturalistik karena penelitiannya dilakukan pada kondisi yang alamiah (natural setting). Metode kualitatif ini dipilih agar data yang diperoleh akan lebih lengkap, lebih mendalam, kredibel dan bermakna sehingga tujuan penelitian dapat dicapai. Menurut Arikunto (2010:32) metode eksploratori adalah metode penelitian yang bertujuan untuk menggali suatu informasi. Ibrahim (2015:61) menjelaskan bahwa pendekatan eksploratori dalam penelitian kualitatif adalah cara kerja penelitian yang dimaksudkan untuk menemukan lebih jauh dan mendalam terhadap kemungkinan-kemungkinan lain dari permasalahan yang diteliti. Dengan pendekatan eksploratori, penelitian tidak lagi sekedar menggambarkan atau melukiskan atau menjelaskan seperti apa adanya realitas yang dikaji sebagaimana pada metode deskriptif. Menurut Satori dan Komariah (2013:103) dalam penelitian kualitatif teknik pengumpulan data dapat dilakukan melalui setting dari berbagai sumber, dan berbagai cara. Adapun teknik pengumpulan data yang digunakan dalam penelitian ini adalah sebagai berikut :

a) Wawancara

Susan Stainback dalam Sugiyono (2015:72) mengemukakan bahwa dengan wawancara, maka peneliti akan mengetahui hal-hal yang lebih mendalam tentang partisipan dalam menginterpretasikan situasi dan fenomena yang terjadi, di mana hal ini tidak bisa ditemukan melalui observasi.

b) Dokumentasi

Menurut Ibrahim (2015:93) dokumen atau dokumentasi dalam penelitian mempunyai 2 (dua) makna yang pertama dokumen yang dimaksudkan sebagai alat bukti tentang sesuatu, termasuk catatan-catatan, foto, rekaman video atau apapun yang dihasilkan oleh peneliti. Kedua dokumen yang berkenaan dengan peristiwa atau momen atau kegiatan yang telah lalu, yang padanya mungkin dihasilkan sebuah informasi, fakta dan data yang diinginkan dalam penelitian.

Secara umum penelitian merupakan suatu proses yang dilakukan selama jangka waktu tertentu dan melakukan pengorbanan waktu tenaga, pikiran dan dana pendapat tersebut juga didukung oleh ahli seperti yang dikatakan oleh Sugiono (2014 2) "Metode penelitian pada dasarnya merupakan cara ilmiah untuk mendapatkan data dengan tujuan dan kegunaan tertentu". Lebih jauh lagi Sugiono juga menjelaskan bahwa ada 2 (dua) jenis metode peneitian. Dalam hal ini peneliti terpokus mengunakan metode kualitatif, metode kualitatif disebut metode baru karena popularitasnya belum lama. Sugiono juga menjelaskan pada filsafal pospositivisme, digunakan untuk meneliti pada obyek yang alamiah.

\section{Metode/Alat Pengumpulan Data}

Untuk mendapatkan suatu informasi yang berkuatlitas maka ada metode atau cara untuk mendapatkannya. Penelitian yang dilakukan dalam rangka untuk mendapatkan informasi. Namun, untuk mendapatkan suatu informasi maka kita perlu mendapatkan data-data yang akurat dan berkualitas. Adapun teknis untuk pengumpulan data pada penelitian ini adalah sebagai berikut :

a. Wawamcara (Interview)

Merupakan suatu teknik pengumpulan data yang dilakukan dengan cara tanya jawab atau dialog secara langsung dengan pihakpihak yang terkait dengan penelitian yang dilakukan. Dalam hal ini peneliti melakukan tanya jawab kepada yang bersangkutan.

Wawancara adalah usaha mengumpulkan informasi dengan mengajukan sejumlah pertanyaan secara lisan, untuk dijawab secara lisan pula. Ciri utama dari wawancara adalah kontak langsung dengan tatap muka (face to face relationship) antara si pencari informasi (interviewer/information hunter) dengan sumber informasi (interviewee). Secara sederhana wawancara diartikan sebagai alat pengumpul data dengan 
mempergunakan tanya jawab antara pencari informasi dan sumber informasi. Materi wawancara adalah tema yang ditanyakan kepada informan, berkisar antara masalah dan tujuan penelitian.

Dalam penelitian kualitatif teknik wawancara merupakan cara utama untuk mengumpulkan data. Wawancara bertujuan untuk menggali tidak saja apa yang diketahui dan dialami oleh informan, tetapi juga apa yang tersembunyi jauh di dalam diri informan. Apa yang ditanyakan kepada informan dapat mencakup hal-hal yang bersifat lintas waktu yang berkaitan dengan masa lampau, masa sekarang dan masa depan

b. Pengamatan (Observasi)

Yaitu dengan pengumpulan data dengan cara mengadakan tinjauan secara langsung ke obyek yang diteliti. Untuk mendapat data yang bersifat nyata dan menyakinkan maka peneliti melakukan pengamatan langsung pada obyek yang bersangkutan.

Jenis dan Sumber Data

Data yang digunakan dalam penelitian ini, yaitu :

1. Data Primer

Menurut Anwar Sanusi (2011:104), data primer adalah data yang pertama kali dicatat dan dikumpulkan oleh peneliti. Dalam penelitian ini, data primer yang dimaksud adalah hasil wawancara secara langsung kepada pihak-pihak yang terkait di Desa. Desa Uma Beringin Kecamatan Unter Iwes, Desa Labuhan Sumbawa Kecamatan Labuhan Badas, Desa Tepal Kecamatan Batulanteh, Desa Batu Rotok Kecamatan Batulanteh, Desa Pulau Bungin Kecamatan Alas, Desa Pulau Kaung Kecamatan Buer, Desa Lekong Kecamatan Alas Barat dan Desa Mapin Rea Kecamatan Alas Barat.

2. Data Sekunder

Menurut Indriantoro dan Supomo (1999) dalam Dwi Febri dan Taufik Kurrohman (2013:483), data sekunder merupakan data penelitian yang diperoleh peneliti secara tidak langsung melalui media perantara atau diperoleh dan dicatat oleh pihak lain. Dalam penelitian ini, juga menggunakan data sekunder sebagai data tambahan yang berupa data-data mengenai profil Desa, beberapa dokumen terkait dengan perencanaan pengelolaan keuangandesa (APBDesa, RPJMDesa, dan RKPDesa) dan beberapa foto dari sarana dan prasarana yang dibangun dengan menggunakan pendapatan desa di Desa Uma Beringin Kecamatan Unter Iwes, Desa Labuhan Sumbawa Kecamatan Labuhan
Badas, Desa Tepal Kecamatan Batulanteh, Desa Batu Rotok Kecamatan Batulanteh, Desa Pulau Bungin Kecamatan Alas, Desa Pulau Kaung Kecamatan Buer, Desa Lekong Kecamatan Alas Barat dan Desa Mapin Rea Kecamatan Alas Barat. Data-data ini bersumber dari bendahara desa yang sangat berperan penting dalam mengatur dan mengurus keuangan desa.

Penelitian ini merupakan penelitian kualitatif yang bersifat deskriptif analitis. Data sekunder diperoleh dari studi pustaka, sedangkan data primer didapatkan melalui hasil penelitian yang diselenggarakan di 8 (delapan) Desa yaitu : Desa Uma Beringin Kecamatan Unter Iwes, Desa Labuhan Sumbawa Kecamatan Labuhan Badas, Desa Tepal Kecamatan Batulanteh, Desa Batu Rotok Kecamatan Batulanteh, Desa Pulau Bungin Kecamatan Alas, Desa Pulau Kaung Kecamatan Buer, Desa Lekong Kecamatan Alas Barat dan Desa Mapin Rea Kecamatan Alas Barat .

\section{Prosedur Analisis Data}

Analisis data menjelaskan cara menganalisis atau teknik mengolah data yang digunakan untuk menarik simpulan dari hasil kajian dari topik yang diteliti.

Analisis data merupakan yang dilakukan setelah data dari seluruh responden atau sumber data lain terkumpul. Dalam hal ini peneliti menganalisis data yang dihasilkan melalui wawancara terhadap subyek penelitian, sehingga peneliti dapat memecahkan pokok persoalan yang timbul dalam penelitian ini.

Analisi data yang digunakan dalam penelitian ini adalah deskriftif kualitatif yang bersifat menggambarkan, memaparkan dan menguraikan obyek yang diteliti (Arikunto, 2006:11). Penelitian kualitatif antara lain bersifat diskriptif, data yang dikumpulkan lebih banyak berupa kata - kata atau gambar dari angka-angka. Dengan demikian penelitian deskriftif kualitatif merupakan penelitian yang bermaksud membuat deskripsi atau gambaran untuk memahami fenomena tentang apa yang dialami oleh subyek penelitian misalnya perilaku, persepsi, motivasi, tindakan dan lain-lain (Melong, 2010:6).

Selanjutnya peneliti dapat menyimpulkan beberapa pokok persoalan berikut pemecahan masalahnya juga peneliti dapat memberikan beberapa saran yang merupakan bagian dari solusi dalam memecahkan persoalan yang timbul dalam penelitian ini.

Menurut Huberman dalam Mukhtar (2013:135) analisis data deskriptif kualitatif mencakup reduksi data, penyajian data, dan 
penarikan kesimpulan, ketiga jalur analisis data tersebut menjadi acuan dalam tulisan ini. Penelitian ini dinyatakan selesai jika data dalam kondisi jenuh, yaitu saat peneliti menanyakan kepada informan yang diwawancarai tentang informan lain yang direkomendasikan, jawabannya tetap berkisar pada informan-informan sebelumnya yang sudah penulis wawancarai.

\section{Reduksi Data}

Reduksi data yaitu sebagai proses pemilihan, pemusatan perhatian pada penyederhanaan, pengabstrakan dan tranformasi data "kasar" yang muncul dari catatan-catatan yang tertulis di lapangan. Reduksi data yang dilakukan penulis dalam penelitian ini adalah analisis yang menajam, menggolongkan, mengarahkan, membuang yang tidak perlu dan mengorganisasi data mengenai Tata Kelola Keuangan Desa yang mengunakan Keuangan Desa di desa yang dijadikan sample ke delapan desa tersebut dengan cara sedemikian rupa sehingga kesimpulan akhirnya dapat ditarik dan diverifikasi.

2. Penyajian Data (Display Data)

Hasil reduksi data kemudian disusun dan disajikan dalam bentuk teksnaratif-deskriptif. Tahap penyajian data berisi tentang pengolahan data setengah jadi yang sudah seragam dalam bentuk tulisan dan sudah memiliki alur tema yang jelas ke dalam suatu matriks kategorisasi sesuai tema-tema yang sudah dikelompokkan dan dikategorikan, serta akan memecah tema-tema tersebut ke dalam bentuk yang lebih konkret dan sederhana.

3. Penarikan Kesimpulan (Conclusion)

Tahap ini adalah tahap akhir analisis data. Kesimpulan menjurus pada jawaban dari pertanyaan dalam rumusan masalah penelitian. Dalam konteks penelitian ini penulis menggunakan indikator untuk mengetahui sejauh mana pengelolaan Dana Desa tersebut. Kemudian berdasarkan hasil temuan dilapangan melalui wawancara dan dokumentasi dilapangan yang dikaitkan dengan kesemua indikator tesebut maka penulis mendapati bahwa beberapa indikator berjalan dengan baik. Untuk mengetahui validitas data peneliti menggunakan triangulasi teknik dan triangulasi sumber. Triangulasi teknik yaitu untuk mengetahui atau menanyakan hal yang sama dengan teknik yang berbeda yaitu wawancara, dokumentasi. Sedangkan triangulasi sumber dilakukan dengan cara menanyakan hal sama melalui sumber/informan yang berbeda dari pihak pemerintah desa, jika sumber data memberikan data yang sama berarti data dikatakan kredibel. Bedasarkan hasil data tersebut sehingga peneliti dapat menarik kesimpulan yang kemudian dipaparkan pada bagian kesimpulan dan saran.

\section{Instrumen Penelitian}

Menurut Sugiyono (2013:146) Instrumen penelitian adalah suatu alat yang digunakan untuk mengukur fenomena alam maupun sosial yang diamati. Instrumen yang digunakan dalam penelitian ini adalah instrument kuisioner metode tertutup, dimana kemungkinan jawaban sudah ditentukan terlebih dahulu dan responden tidak diberikan alternatif jawaban. Indikator-indikator untuk variable tersebut dijabarkan oleh peneliti menjadi sejumlah pertanyaan sehingga diperoleh data kualitatif. Data ini akan diubah menjadi bentuk kuantitatif dengan pendekatan analisis statistik.

Secara umum teknik dalam pemberian skor yang digunakan dalam kuisioner ini adalah teknik skala likert. Penggunaan skala likert menurut Sugiono (2013:132) skala likert digunakan untuk mengukur sikap, pendapat dan persepsi seseorang atau sekelompok orang tentang fenomena sosial".

Pada penelitian ini peneliti menggunakan bobot nilai 1 dan 0.1 untuk jawaban benar sesuai dengan harapan peneliti dan 0 untuk jawaban yang salah atau yang tidak sesuai dengan harapan peneliti. Dari perolehan nilai pada masing - masing pertanyaan pada kuisioner maka dapat diprentasekan dengan rumus:

Skala Likert Bernilai Positif

\begin{tabular}{|l|c|}
\hline \multicolumn{1}{|c|}{ Kualifikasi } & Skala Persentase \\
\hline Tidak Sesuai (TS) & 1 \\
\hline Sesuai (S) & 2 \\
\hline
\end{tabular}

Rumus persentase yang digunakan dalam adaptasi adalah :

$$
\mathrm{R}=\frac{S P}{S T} \times 100 \%
$$

$$
\begin{aligned}
\text { Keterangan : } & \mathrm{R}=\text { Nilai Porsentase } \\
& \mathrm{SP}=\text { Skor Perolehan } \\
& \mathrm{ST}=\text { Skor Ideal atau skor yang } \\
& \text { diharapkan }
\end{aligned}
$$

Selanjutnya untuk mengetahui factor-faktor yang sangat berpengaruh terhadap Penyampaian laporan maka digunakan skala prosentase sebagai berikut:

Skala Likert Bernilai Negatif

\begin{tabular}{|l|c|}
\hline \multicolumn{1}{|c|}{ Kualifikasi } & Skala Persentase \\
\hline Sangat Berperan & $81-100$ \\
\hline Berperan & $61-80$ \\
\hline
\end{tabular}




\begin{tabular}{|l|c|}
\hline Cukup Berperan & $41-60$ \\
\hline Tidak Berperan & $21-40$ \\
\hline
\end{tabular}

\section{HASIL DAN PEMBAHASAN}

\section{Pelaksanaan Penelitian}

Penelitian ini dilaksanakan bulan Desember 2018 sampai bulan Juni 2019 di Desa Uma Beringin Kecamatan Unter Iwes, Desa Labuhan Sumbawa Kecamatan Labuhan Badas, Desa Tepal Kecamatan Batulanteh, Desa Batu Rotok Kecamatan Batulanteh, Desa Pulau Bungin Kecamatan Alas, Desa Pulau Kaung Kecamatan Buer, Desa Lekong Kecamatan Alas Barat dan Desa Mapin Rea Kecamatan Alas Barat.

\section{Hasil Penelitian}

Wawancara dilakukan sesuai dengan pedoman wawancara kepada informan kunci yang sudah ditentukan dan digunakan alat perekam untuk merekam seluruh isi wawancara, serta menggunakan instrumen pendukung antara lain buku catatan, alat perekam berupa HP untuk mendokumentasikan kegiatan dilapangan dan laptop untuk mengetik hasil penelitian dan rekaman sehingga berbentuk transkrip wawancara yang kemudian direduksi dan ditentukan tema berdasarkan permasalahan pada bab sebelumnya. Untuk menjawab masalah pertama yaitu : bagaimana pengelolaan dan pemanfaatan Dana Desa adalah 5 (lima) tema yaitu : perencanaan, pelaksanaan, penatausahaan, pelaporan, pertanggungjawaban. Untuk menjawab masalah kedua yaitu : hambatan-hambatan apa saja dalam pengelolaan dan pemanfaatan Dana Desa adalah : hambatan sumber daya, hambatan letak geografis. Dan hambatan geografis ini dikelompokkan dalam hambatan sumber daya.kemudian didapatkan juga upaya untuk mengatasi hambatan tersebut

Dalam Pengelolaan Dan Pemanfaatan Dana Desa mengacu pada Peraturan Menteri Dalam Negeri Nomor 113 Tahun 2014.

Pemerintah Desa menyusun perencanaan pembangunan desa sesuai dengan kewenangannya dengan mengacu pada perencanaan pembanguanan Kabupaten/Kota. Perencanaan pembangunan desa meliputi RPJMDes dan RKPDesa yang disusun secara berjangka dan ditetapkan dengan Peraturan Desa.

RKPDes merupakan dasar dalam penyusunan Rancangan APBDes (RAPBDes). Teknis penyusunan RPJMDes dan RKPDes agar tercipta keselarasan telah diatur tata caranya dalam Pemendagri Nomor 114 Tahun 2014 tentang Pedoman Pembangunan Desa. Setelah RKPDes ditetapkan maka dilanjtkan proses penyusunan APBDes. Rencana Kegiatan dan Rencana Anggara Biaya yang telah ditetapkan dalam RKPDes dijadikan pedoman dalam proses penganggaranya. Anggaran Pendapatan dan Belanja Desa (APBDes) merupakan rencana anggaran keuangan tahunan pemerintah desa yang ditetapkan untuk menyelenggarakan program dan kegiatan yang menjadi kewenangan desa.

Anggaran Pendapatan dan Belanja Desa (APBDes) adalah instrumen penting yang sangat menentukan dalam rangka perwujudan tata pemerintahan yang baik (good governance) ditingkat desa. Tata Pemerintahan yang baik diantaranya diukur dari proses penyusunan dan pertanggungjawaban APBDes. Memahami proses seluruh tahapan pengelolaan APBDes (penyusunan, pelaksanaan, pertanggungjawaban) memberikan arti terhadap model penyelenggaraan pemerintahan desa itu sendiri.

Proses pengelolaan APBDes yang berdasarkan pada perinsip partisipasi, transparasi dan akuntabilitas akan memberikan arti dan nilai bahwa pemerintahan desa dijalankan dengan baik. APBDes yang memadai juga dapat mendorong partisipasi warga lebih luas daripada proses- proses perencanaan dan penganggaran pembangunan. APBDesa dapat menjawab partisipasi warga yang bersifat mikro dan mampu ditangani pada level desa.

Proses penguatan Pemerintahan Desa (Pemerintah Desa dan Badan Permusyawaratan Desa) perlu dilakukan dalam pengelolaan keuangan desa, khususnya tahap penyusunan, pelaksanaan dan pertanggungjawaban APBDes yang disusun berorentasi kepada peningkatan kesejahteraan masyarakat desa dan memenuhi perinsip-perinsip good governance seperti taransparasi, partisipasi, efektivitas dan akuntabilitas.

\section{Perencanaan}

Sekretaris desa menyusun rancangan APBDesa berdasarkan RKPDesa kemudian disampaikan kepada kepala desa dan selanjutnya disampaikan kepala desa kepada BPD untuk pembahasan selanjutnya pembahasan melalui musyawarah desa untuk menetapkan program prioritas pembangunan yang ada di desa. Untuk perencanaan terdapat kesesuaian tapi untuk jadwal yang seharusnya bulan Oktober tahun berjalan dilaksanakan pada bulan Januari sampai Februari karena menunggu jadwal dari pemerintah daerah. Begitu juga untuk kegiatan Rancangan APBDesa yang sudah ditetapkan kadang kegiatan yang sudah ada tidak sesuai dengan apa yang ada di SISKEUDES sehingga harus melakukan perubahan kegiatan menyesuaikan dengan apa yang ada di SISKEUDES. Dalam perencanaan sudah sesuai dengan apa yang menjadi kebutuhan dasar masyarakat, karena APBDesa yang sudah disepakati bersama melalui musrembang desa telah disetujui oleh BPD. Namun pada kenyataannya terbentur dengan regulasi yang sudah dijabarkan melalui 
SISKEUDES dimana apa yang sudah diprogramkan tidak termuat dalam SISKEUDES dan ini merupakan salah satu hambatan.

\section{Pelaksanaan}

Pada proses pelaksanaan kegiatan pengelolaan Dana Desa, kepala desa mengangkat Pelaksana Teknis Kegiatan (PTK) yang pekerjaannya mengawasi dan mengkoordinasi pekerjaan di lapangan. Proses selanjutnya ketika masuk dalam pelaksanaan keuangan maka PTK membuat faktur belanja yang disesuaikan dengan Rencana Anggaran Biaya (RAB). Tim pemeriksa barang yang akan menyatakan barang sesuai dengan nota pesanan atau tidak, barang itu layak atau tidak. Apabila layak maka pelaksana kegiatan membuat Surat Perintah Pembayaran (SPP) dan dimasukan kepada kepala desa sebagai Kuasa Pengguna Anggaran (KPA) yang kemudian kepala desa memberikan disposisi kepada Pelaksana Teknis Pengelolaan Keuangan Desa (PTPKD). Tim pemeriksa barang akan membuat berita acara bahwa barang tersebut adalah benar-benar baik dan sesuai dengan nota pesanan nomor sekian. Kalau sudah dinyatakan sah dan layak dibayar oleh pemeriksa barang maka pelaksana kegiatan mengajukan Surat Perintah Membayar (SPM) kepada kepala desa. Kepala desa sebagai Kuasa Pengguna Anggaran (KPA) akan memberikan disposisi kepada PTPKD supaya boleh menindaklanjuti sehingga prosesnya berjalan baik. Dalam hal ini bendahara hanya bertugas membayar dan menyimpan uang yang sudah dicairkan dari bank, sedangkan sekretaris desa yang mengetahui persis belanja pengeluaran karena sekretaris desa sebagai verifikator.

\section{Penatausahaan}

Pada proses penatausahaan pengelolaan Dana Desa sudah sesuai dengan Peraturan Menteri Dalam Negeri Nomor 113 tahun 2014 tentang Pengelolaan Keuangan Desa

\section{Pelaporan}

Laporan Dana Desa adalah 2 (dua) semester dimana semester pertama adalah bulan Juli dan semester kedua adalah bulan Januari tahun selanjutnya.

\section{Pertanggungjawaban}

Pada proses pertanggungjawaban ini di mulai dari setiap dana yang keluar dicatat oleh bendahara dikelola oleh PTPKD termasuk sama-sama dengan sekretaris desa selaku koordinator PTPKD untuk membuat laporan. Kemudian disampaikan kepada kepala desa untuk dikaji kebenarannya apa masih ada yang tidak dilaporkan atau masih ada kesalahankesalahan, karena kepala desa adalah Kuasa Pengguna Anggaran (KPA).

\section{Hambatan dan Upaya Mengatasi Hambatan Dalam Pengelolaan dan Pemanfaatan Dana Desaadalah : Hambatan Sumber Daya}

Dalam pengelolaan dan pemanfaatan Dana Desa ditemukan 3 (tiga) faktor penghambat dalam sumber daya yaitu sumber daya manusia, sarana prasarana dan keadaan letak geografis. Sumber daya manusia berkenan dengan kemampuan bendahara yang tidak bisa mengoperasikan leptop bahkan tidak mengerti sistem SISKEUDES sehingga masih diperlukan pelatihan-pelatihan untuk meningkatkan kemampuan dari bendahara dalam melakukan pertanggungjawaban pengelolaan Dana Desa. Silalahi (2015 : 242) menyatakan SDM merupakan elemen penting dan merupakan aset terpenting dari organisasi dibanding dengan elemen lainnya. Manusia dalam organisasi memiliki peran dan fungsi penting bagi terwujudnya tujuan organisasi. Manusia yang membuat sumber-sumber lain dari suatu organisasi bekerja dan membuat organisasi bergerak.

Selanjutnya sumber daya bukan manusia atau sumber daya material adalah berbagai fasilitas sarana prasarana yang dibutuhkan untuk mendukung pencapaian tujuan. Sebab meskipun manusia menjadi elemen penting dan menentukan dalam pencapaian tujuan keorganisasian tetapi jika tidak disertai atau didukung oleh sumber daya material yang memadai, maka tujuan yang sudah ditetapkan tidak akan tercapai secara optimum Silalahi (2015 :261). Hambatan sumber daya kedua adalah sarana prasarana yang tidak memadai misalnya tidak ada jaringan internet yang menyebabkan ketinggalan informasi dalam mengakses peraturan atau pun informasi tentang pengelolaan Dana Desa ini. Pemerintah desa hanya menunggu informasi yang disampaikan oleh pemerintah daerah. Hal ini juga menyebabkan terhambatnya penyampaian informasi kepada masyarakat tentang pengelolaan Dana Desa.

Hambatan yang ketiga yang dikelompokan dalam hambatan sumber daya adalah letak geografis.Karena letak geografis ini banyak mengalami keterlambatan dalam informasi mengenai Dana Desa. Letak geografis merupakan salah satu hambatan dalam pengelolaan Dana Desa pada desa Batu Rotok dan desa Tepal Kecamatan Batulanteh karena desa tersebut ini pada bulan tertentu cuacanya sangat ekstrim sehingga masyarakat untuk melakukan aktivitasnya ke kota tidak ada. Ini terjadi karena dari kota kabupaten menuju ke desa ini harus menempuh perjalanan dengan menggunakan sepeda motor dan hartop yang merupakan alat transportasi masyarakat setempat dengan waktu kurang lebih 4 s.d 6 (empat sampai dengan enam) jam. Hal ini juga mengakibatkan biaya (harga) barang meningkat sehingga kadang 
sulit menyesuaikan dengan apa yang sudah ditetapkan dalam RAB oleh tim PTPKD.

\section{Upaya mengatasi hambatan Sumber Daya}

Mengatasi hambatan sumber daya ini terutama sumber daya manusia, pemerintah desa seharusnya berkoordinasi dengan pemerintah daerah untuk melaksanakan pelatihan tentang pengelolaan keuangan desa dalam rangka meningkatkan profesionalisme dari tim PTPKD terutama bendahara dan sekretaris desa. Silalahi (2015 : 242) menyatakan sumber daya manusia merupakan elemen penting dan merupakan aset terpenting dari organisasi dibanding dengan elemen lainnya. Manusia dalam organisasi memiliki peran dan fungsi penting bagi terwujudnya tujuan organisasi. Manusia yang membuat sumber-sumber lain dari suatu organisasi bekerja dan membuat organisasi bergerak.

Pedoman Pengukuran Hasil Analisis Data Hasil

\begin{tabular}{|c|c|c|c|c|c|}
\hline \multicolumn{6}{|c|}{ Wawancara } \\
\hline No. & Aspek & Sub Aspek & $\begin{array}{l}\text { Jmh } \\
\text { Item }\end{array}$ & $\begin{array}{l}\text { Sk or } \\
\text { Ideal }\end{array}$ & $\begin{array}{l}\text { Total } \\
\text { Skor }\end{array}$ \\
\hline & $\begin{array}{l}\text { Kesesuaian } \\
\text { Perencanaan } \\
\text { Dana Desa }\end{array}$ & $\begin{array}{l}\text { a. Kesesuaian } \\
\text { antara hasil } \\
\text { MusrenbangDes } \\
\text { dengan RKPDes } \\
\text { b. RKPDes } \\
\text { disahkan, maka } \\
\text { tim penyusun } \\
\text { selanjutnya } \\
\text { membuat } \\
\text { RAPBDes } \\
\text { c. RAPBDes } \\
\text { dilaporkan } \\
\text { kepada BPD dan } \\
\text { melalui } \\
\text { musyawarah } \\
\text { desa dan } \\
\text { ditetapkan } \\
\text { bersama dengan } \\
\text { BPD dalam } \\
\text { bentuk peraturan } \\
\text { desa. } \\
\text { d. Penetapan } \\
\text { RAPBDespaling } \\
\text { lambat bulan } \\
\text { Desember tahun } \\
\text { anggaran } \\
\text { sebelumnya }\end{array}$ & 1 & 2 & 8 \\
\hline & $\begin{array}{l}\text { Kesesuaian } \\
\text { Pelaksanaan } \\
\text { Dana Desa }\end{array}$ & $\begin{array}{l}\text { a. semua } \\
\text { pemasukan dan } \\
\text { pengeluaran } \\
\text { harus melalui } \\
\text { rekening desa. } \\
\text { b. Setiap } \\
\text { pelaksanaan } \\
\text { kegiatan } \\
\text { mengajukan } \\
\text { RAB kegiatan. } \\
\text { c. Segala bentuk } \\
\text { pengeluaran } \\
\text { kegiatan melalu } \\
\text { ADD tetap } \\
\text { dipertanggungja } \\
\text { wabkan }\end{array}$ & 1 & 2 & 8 \\
\hline
\end{tabular}

\begin{tabular}{|c|c|c|c|c|}
\hline & $\begin{array}{l}\text { d. Pengajuan SPP } \\
\text { melalui Sekdes } \\
\text { dengan } \\
\text { persetujuan } \\
\text { Kepala Desa }\end{array}$ & & & \\
\hline $\begin{array}{l}\text { Kesesuaian } \\
\text { Penatusahaa } \\
\text { n Dana Desa }\end{array}$ & $\begin{array}{l}\text { a. Penatausahaan } \\
\text { dilakukan oleh } \\
\text { bendahara desa } \\
\text { b. siskeudes } \\
\text { yangsecara } \\
\text { otomatis akan } \\
\text { membantu tugas } \\
\text { bendahara desa } \\
\text { dalam } \\
\text { melakukanpenata } \\
\text { usahaan } \\
\text { c. Bendahara desa } \\
\text { wajib } \\
\text { mempertanggung } \\
\text { jawabkan uang } \\
\text { melalui laporan } \\
\text { Pertanggungjawa } \\
\text { ban }\end{array}$ & 1 & $\begin{array}{l}2 \\
2\end{array}$ & 6 \\
\hline $\begin{array}{l}\text { Kesesuaian } \\
\text { pelaporan } \\
\text { Dana Desa }\end{array}$ & 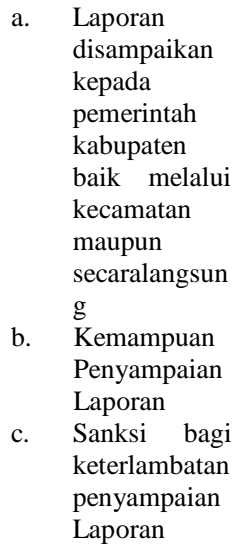 & 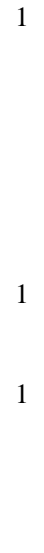 & 2 & 6 \\
\hline $\begin{array}{l}\text { Kesesuaian } \\
\text { Pertanggung } \\
\text { jawaban } \\
\text { Dana Desa }\end{array}$ & $\begin{array}{ll}\text { a. } & \text { Laporan } \\
& \text { pertanggungja } \\
& \text { waban telah } \\
& \text { disampaikan } \\
\text { pada akhir } & \\
\text { tahun } \\
\text { b. } \\
\text { laporan ADD } \\
\text { terintergrasi } \\
\text { dengan } \\
\text { laporan } \\
\text { APBDes } \\
\text { menyampaika } \\
\text { n laporan } \\
\text { pertanggungja } \\
\text { waban kepada } \\
\text { masyarakat } \\
\text { melalui forum } \\
\text { musyawarah }\end{array}$ & 1 & 2 & 6 \\
\hline \multicolumn{2}{|r|}{ Jumlah } & 17 & 100 & 100 \\
\hline
\end{tabular}

Rekapitulasi Perhitungan Persentase 
SPECIAL ISSUE

JURNAL TAMBORA VOL. 4 NO. 2A JULI 2020

http://jurnal.uts.ac.id

Sacial Humaniara

\begin{tabular}{|c|c|c|c|c|c|}
\hline \multirow{2}{*}{ No. } & \multirow{2}{*}{$\begin{array}{c}\text { Komponen } \\
\text { Aspek }\end{array}$} & \multicolumn{3}{|c|}{ Skor Perolehan } & \multirow{2}{*}{ Kualifikasi } \\
\hline & & Sp & $\mathbf{S i}$ & Total & \\
\hline 1 & $\begin{array}{l}\text { Kesesuaian } \\
\text { Perencanaan } \\
\text { Dana Desa }\end{array}$ & 5,5 & 8 & 68,75 & Berpengaruh \\
\hline 2 & $\begin{array}{l}\text { Kesesuaian } \\
\text { Pelaksanaan } \\
\text { Dana Desa }\end{array}$ & 5,3 & 8 & 66,25 & Berpengaruh \\
\hline 3 & $\begin{array}{l}\text { Kesesuaian } \\
\text { Penatausahaan } \\
\text { Dana Desa }\end{array}$ & 4,9 & 6 & 81,6 & $\begin{array}{c}\text { Sangat } \\
\text { Berpengaruh }\end{array}$ \\
\hline 4 & $\begin{array}{l}\text { Kesesuaian } \\
\text { Pelaporan } \\
\text { Dana Desa }\end{array}$ & 5,2 & 6 & 86,6 & $\begin{array}{c}\text { Sangat } \\
\text { Berpengaruh }\end{array}$ \\
\hline 5 & $\begin{array}{l}\text { Kesesuaian } \\
\text { Pertanggung } \\
\text { jawaban Dana } \\
\text { Desa }\end{array}$ & 5,4 & 6 & 90 & $\begin{array}{c}\text { Sangat } \\
\text { Berpengaruh }\end{array}$ \\
\hline & Jumlah & 26,3 & 34 & 393,2 & \\
\hline & $\begin{array}{l}\text { Rata-rata } \\
\text { Perolehan }\end{array}$ & 5,26 & 6,8 & 78,64 & Berpengaruh \\
\hline
\end{tabular}

\begin{tabular}{|c|l|c|c|c|c|c|}
\hline $\mathbf{5}$ & $\begin{array}{l}\text { Pulau } \\
\text { Kaung }\end{array}$ & 4 & 1.597 & 55 & $\mathrm{Rp} \mathrm{1.319.928.747,83}$ & $50 \%$ \\
\hline $\mathbf{6}$ & $\begin{array}{l}\text { Pulau } \\
\text { bungin }\end{array}$ & 4 & 3.161 & 66,4 & $\mathrm{Rp} \mathrm{1.642.262.618,00}$ & $45 \%$ \\
\hline $\mathbf{7}$ & Lekong & 4 & 2.590 & 75 & $\mathrm{Rp} \mathrm{1.684.887.647,00}$ & $55 \%$ \\
\hline $\mathbf{8}$ & Mapin Rea & 4 & 3.142 & 82 & $\mathrm{Rp} \mathrm{1.904.065.864,00}$ & $60 \%$ \\
\hline
\end{tabular}

Laporan Pertanggung Jawaban Bulan Juli 2019

\begin{tabular}{|l|l|c|c|c|c|c|}
\hline NO & NAMA DESA & $\begin{array}{c}\text { JENIS } \\
\text { LAPO } \\
\text { RAN }\end{array}$ & $\begin{array}{c}\text { JML } \\
\text { PDDK }\end{array}$ & $\begin{array}{c}\text { JARAK } \\
\text { KMMU }\end{array}$ & $\begin{array}{c}\text { ALOKASI DANA } \\
\text { DESA (Rp) }\end{array}$ & $\begin{array}{c}\% \\
\text { PENYA } \\
\text { MPAIAN } \\
\text { LAPO } \\
\text { RAN }\end{array}$ \\
\hline $\mathbf{1}$ & $\begin{array}{l}\text { Labuhan } \\
\text { Sumbawa }\end{array}$ & 4 & 14.981 & 2,5 & Rp 2.506.068.500,00 & $90 \%$ \\
\hline $\mathbf{2}$ & Uma Bringin & 4 & 2.372 & 1 & Rp 1.376.400.700,00 & $82 \%$ \\
\hline $\mathbf{3}$ & Batu Rotok & 4 & 3.819 & 62 & $\mathrm{Rp} 2.617 .504 .355,00$ & $73 \%$ \\
\hline $\mathbf{4}$ & Tepal & 4 & 1.673 & 48 & $\mathrm{Rp} \mathrm{2.254.171.600,00}$ & $77 \%$ \\
\hline $\mathbf{5}$ & Pulau Kaung & 4 & 1.601 & 55 & $\mathrm{Rp} 1.415 .697 .200,00$ & $80 \%$ \\
\hline $\mathbf{6}$ & Pulau bungin & 4 & 3.171 & 66,4 & $\mathrm{Rp} 1.771 .371 .800,00$ & $85 \%$ \\
\hline $\mathbf{7}$ & Lekong & 4 & 2.609 & 75 & $\mathrm{Rp} \mathrm{1.679.275.800,00}$ & $79 \%$ \\
\hline $\mathbf{8}$ & Mapin Rea & 4 & 3.146 & 82 & $\mathrm{Rp} 1.485 .602 .557,00$ & $80 \%$ \\
\hline
\end{tabular}

Laporan Pertanggung Jawaban p 31 Desember 2018

\begin{tabular}{|c|c|c|c|c|c|c|}
\hline No & $\begin{array}{c}\text { NAMA } \\
\text { DESA }\end{array}$ & \begin{tabular}{|c} 
JENIS \\
LAPORA \\
$\mathbf{N}$
\end{tabular} & JML PDDK & $\begin{array}{c}\text { JARAK } \\
\text { TEMPU } \\
\text { H KM }\end{array}$ & $\begin{array}{c}\text { ALOKASI DANA } \\
\text { DESA (Rp) }\end{array}$ & $\begin{array}{c}\% \\
\text { PENYA } \\
\text { MPAIA } \\
\mathbf{N} \\
\text { LAPOR } \\
\text { AN }\end{array}$ \\
\hline 1 & $\begin{array}{l}\text { Labuhan } \\
\text { Sumbawa }\end{array}$ & 4 & 14.697 & 2,5 & Rp 2.946.134.631,60 & $70 \%$ \\
\hline 2 & $\begin{array}{l}\text { Uma } \\
\text { Bringin }\end{array}$ & 4 & 2.351 & 1 & Rp 1.601.617.500,00 & $72 \%$ \\
\hline 3 & Batu Rotok & 4 & 3.816 & 62 & $\mathrm{Rp} 2.350 .348 .800,00$ & $48 \%$ \\
\hline 4 & Tepal & 4 & 1.672 & 48 & Rp $1.999 .323 .500,00$ & $50 \%$ \\
\hline
\end{tabular}

Perbandingan Penyampaian Laporan Bulan Desember 2018 dan Bulan Juni 2019

\begin{tabular}{|c|l|c|c|c|c|}
\hline No. & Nama Desa & $\begin{array}{c}\text { Per- } \\
\text { Desember } \\
2018\end{array}$ & $\begin{array}{c}\text { Per-Juli } \\
2019\end{array}$ & Selisih & $\begin{array}{c}\text { Jarak } \\
\text { Tempuh }\end{array}$ \\
\hline 1 & $\begin{array}{l}\text { Labuhan } \\
\text { Sumbawa }\end{array}$ & $70 \%$ & $90 \%$ & $20 \%$ & 2,5 \\
\hline 2 & Uma Bringin & $72 \%$ & $82 \%$ & $10 \%$ & 1 \\
\hline 3 & Batu Rotok & $48 \%$ & $73 \%$ & $25 \%$ & 62 \\
\hline 4 & Tepal & $50 \%$ & $77 \%$ & $27 \%$ & 48 \\
\hline 5 & Pulau Kaung & $50 \%$ & $80 \%$ & $30 \%$ & 55 \\
\hline
\end{tabular}




\begin{tabular}{|c|l|c|c|c|c|}
\hline 6 & Pulau Bungin & $45 \%$ & $85 \%$ & $40 \%$ & 66,4 \\
\hline 7 & Lekong & $55 \%$ & $79 \%$ & $24 \%$ & 75 \\
\hline 8 & Mapin Rea & $60 \%$ & $80 \%$ & $20 \%$ & 82 \\
\hline
\end{tabular}

Setelah dilakukannya Pendidikan dan Pelatihan Sistem Keuangan Desa (SISKEUDES) oleh Dinas Pemberdayaan Masyarakat dan Desa Kabupaten Sumbawa kepada Bendahara desa maka meningkatlah pengetahuan Bendahara Desa tentang pegelolaan keuangan desa dilihat dari Penatausahaan. Dalam proses Penantausahaan pengelolaan dana desa sudah sesuai dengan Peraturan Menteri Dalam Negeri Nomor 113 Tahun 2014, begitu juga dengan Pelaporan dana desa dilaporkan 2 (dua) kali setahun yaitu laporan semesteran ; laporan semester petama dilakukan pada bulan Juli pata tahun berjalan dan laporan semester kedua dilakukan pada bulan Januari pada tahun selanjutnya dan Pertanggungjawaban yang dilakukan oleh bendahara desa mempunyai tugas untuk menerima, menyimpan, menyetorkan dan membayar setiap dana yang keluar selalu dicatat sebagai pertanggungjawaban. Dengan pengetahuan yang telah diterima dalam Pendidikan dan Pelatihan Sistem Keuangan Desa (Siskeudes) Bendahara Desa menjadi paham dalam pengoprasian aplikasi Siskeudes sehingga laporan mulai dari Perencanaan, Pelaksanaan, Penatausahaan, pelaporan dan sampai Pertanggungjawaban Pengelolaan Keuangan Desa sudah tidak menjadi hambatan dalam pengetahuan yang sudah diterima di dalam Diklat tersebut dilihat dari pelaporan yang disajikan oleh bendahara desa.

\section{PENUTUP}

\section{Kesimpulan}

Dari hasil penelitian dan pembahasan yang telah dikemukakan pada bab sebelumnya, peneliti mengambil kesimpulan :

1. Penerapan inovasi proses dalam percepatan penyampaian laporan keuangan oleh pemerintah desa khususnya bendahara desa melalui pelatihan siskeudes oleh Dinas Pemberdayaan Masyarakat Desa Kabupaten Sumbawa hal tersebut dapat lihat dari perbandingan ketepatan waktu penyampaian laporan Keuangan priode bulan Desember 2018-Juni 2019 mengalami peningkatan pada penyampaian laporan baik laporan semesteran maupun laporan tahunan karena telah dilakukan Diklat bagi bendahara desa bersangkutan.

2. Kendala yang dihadapi dalam melakukan inovasi proses yaitu pelatihan siskeudes bagi bendahara desa dalah :

a. latar belakang pendidikan dan kemampuan menerima materi pelatihan siskeudes sehingga mempengaruhi kualitas output pelatihan. b. Keterbatasan anggaran pelatihan sehingga dilaksanakan satu kali dalam setahun hanya terfokus pada tahapan pelaporan keuangan desa yang idealnya dilaksanakan setiap siklus pengelolaan keuangan desa mulai dari perencanaan, Pengganggaran, Pelaksanaan, Penatausahaan, Pelaporan dan Pertanggungjawaban.

\section{Saran}

1. Untuk kedepannya, pemerintah Kabupaten dalam hal ini Dinas Pemberdayaan Masyarakat dan Desa sering melakukan Monitoring dan Evaluasi di wilayah yang sulit di jangkau oleh jaringan telekomunikasi sehingga segala bentuk informasi yang ada dalam perubahan aturan yang ada mengenai pengelolaan keunagan sehingga pemerintah desa tidak mengalami keterlambatan dalam penyampaian laporan. Dan atau bendahara desa proaktif untuk menggali informasi tentang pengelolaan keuangan desa dikarenakan petugas Kabupaten dalam hal ini personil atau staf yang ada di bidang Pemerintahan Desa sangat terbatas tidak memungkinkan untuk turun ke seluruh desa di kabupaten sumbawa yang begitu luas dan banyaknya desa yang berjumlah 157 desa sehingga diharapkan bendara desa khusunya pengelola keuangan desa datang ke Kabupaten.

2. Pemerintah desa hendaknya meningkatkan pengetahuan dan kemampuan aparat desa dalam pengelolaan keuangan desa supaya semua perangkat mempunyai pemahaman yang sama tujuannya adalah supaya membantu keberhasilan pengelolaan Alokasi Dana Desa pada khususnya dan keuangan desa pada umumnya.

3. Dalam penelitian selanjutnya hendaknya lebih diperluas. Karena dalam penelitian ini terbatas pada pengelola keuangan desa saja, tidak sampai pada pembinaan dan pengawas pengelolaan keuangan desa.

\section{REFERENSI}

https://jurnal.polibatam.ac.id/index.php/JAEMB/art icle/download/536/402/

BPKP.(2005). Petunjuk Pelaksana Bimbingan dan Konsultasi Pengelolaan Keuangan Desa. Deputi Bidang Pengawasan Penyelenggaraan Keuangan Daerah.

Permendagri No.113 Tahun 2014 Tentang Pengelolaan Keuangan Desa

Peraturan Menteri Dalam Negeri Nomor 84 Tahun 2015 tentang Struktur Organisasi dan Tata Kerja Pemerintah Desa 
Badan Pengawasan Keuangan dan Pembangunan. Halaman

http://www.bpkp.go.id/public/upload/unit panduan pengelolaan keuangan desa. Petunjuk Pelaksanaan Bimbingan Dan Konsultasi Pengelolaan Keuangan Desa. Diunduh pada tanggal 2 April 2019.

Badan Pengawasan Keuangan dan Pembangunan. Halaman

http://www.bpkp.go.id/konten/1737/WartaPengawasan-BPKP-Situs Resmi BPKP 2017. Diunduh pada tanggal 4 Maret 2019.

. 2010. Peraturan Pemerintah Nomor 71 Tahun 2010 tentang Standar Akuntansi Pemerintah. 22 Oktober 2010. Lembaran Negara Republik Indonesia No. 123.
Direktorat Jendral Perimbangan Keuangan Kementrian Keuangan. 2015. Rincian Dana Desa Tahun Anggaran 2016. Halaman http://www.djpk.kemenkeu.go.id/web/attach ment/article/608/DANA DESA2016.pdf. Diunduh pada tanggal 4 April 2019.

Direktorat Jenderal Perimbangan Keuangan Kementrian Keuangan. Halaman www.djpk.depkeu.go.id/wp/2016/03/03

Penggunaan Dana Desa Kemendes. Diunduh pada tanggal 4 April 2019.

Republik Indonesia. Undang-Undang Nomor 6 Tahun 2014 tentang Desa. Jakarta.

Sugoyono. (2010). Metode Penelitian Kulitatif Kuanntitatif Bandung : Alfabeta 